\title{
The correlation that distance between world heritage sites and international airports has on visitation levels
}

\author{
Jocelyne Napoli ${ }^{1}$, Ben Trapman ${ }^{2}$ \\ University of Toulouse, France ${ }^{1,2}$ \\ jocelyne.napoli@univ-tlse3.fr ${ }^{1}$, ben.trapman@univ-tlse3.fr ${ }^{2}$
}

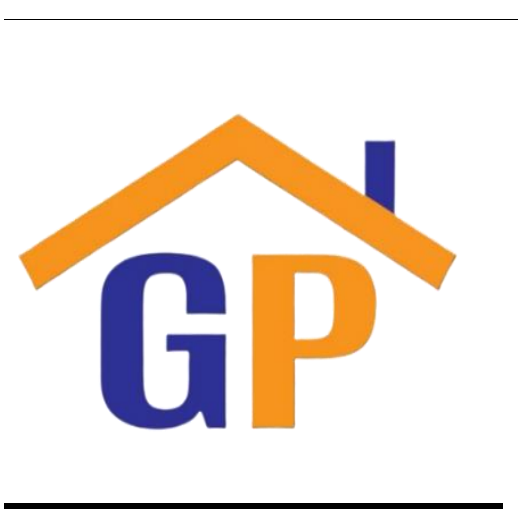

Article History

Received on 18 May 2020

Revised on 6 August 2020

Accepted on 7 August 2020

\begin{abstract}
Purpose: This article illustrates the comparative analysis that was performed on the 2018/2019 official databases of international airports and UNESCO WHS. This analysis was carried out to find connections between both air passenger and visitation levels for strategic leveraged purposes within tourism.
\end{abstract}

Research methodology: Three databases were used in this analysis. The first database collects official data regarding airports such as their geographical position. The second includes data regarding the distance between WHS and international airports, while the third entails both air passenger arrivals and WHS visitation statistics.

Results: Hence, this paper attempts to present the correlation that distance between WHS and International Airports has on visitation levels without claiming causation in any way.

Contribution: The implications of this innovative research will stimulate future academic research interests and allow government departments, tourism entities, and other stakeholders to conduct further research and develop future strategies and action plans.

Keywords: World heritage sites, Tourism, Air transport, Economics, Management

How to cite: The correlation that distance between world heritage sites and international airports has on visitation levels. (2019). Journal of Sustainable Tourism and Entrepreneurship, 1(1), 37-54.

\section{Introduction}

Data was captured for both visitation and arrivals, presenting unbiased opinions founded on raw data alone and does not intend to put forward a hypothesis at this stage of research. Limits to the methodology outlined in the paper are subject to only WHS sites and International Airports included in this paper. World Heritage listed-sites have been reported as enablers of tourism and that proximate access to air transportation can further develop this growth (Lyck, 2015). However, the latter assumption has not been subject to a rigorous econometric approach in the existing literature to date.

A World Heritage site is defined as a landmark or area which is selected by the United Nations Educational, Scientific and Cultural Organization (UNESCO) as having cultural, historical, scientific or other form of significance, and is legally protected by international treaties. The sites are judged important to the collective interests of humanity and are categorized as either Cultural, Natural, and or Mixed.

UNESCO works to create the conditions for dialogue among civilizations, cultures and peoples, based upon respect for commonly shared values (UNESCO, 2018). Therefore, UNESCO listed sites were chosen among all the possible tourism destination types for the scope of this research. Since the $43^{\text {rd }}$ session of the World Heritage Committee in Baku between $30^{\text {th }}$ June and $10^{\text {th }}$ July 2019, there are currently 1,121 World Heritage sites in the world, with 869 cultural locations and 213 natural sites, and 39 mixed properties (43rd session of the Word Heritage Committee, 2019). As air transport plays a vital role within global tourism, the international Civil Aviation Organization (ICAO) and the United 
Nations World Tourism Organization (UNWTO, 2013) signed the Special Joint Statement on aviation and tourism in 2013 to solidify their pact and agreement to mutually move forward on future challenges such as passenger flow management at airports, air capacity for least developed countries and the reduction of the environmental impact that tourism and air transport poses.

The emergence of new air carriers creating niche, low-cost markets within the air transportation sector has been linked to the deregulation and liberalization of the sector since 1978 in America and the midnineteen eighties in the European Union (Zajac, 2016). Considering the forecasted increase in air transportation demands as per the International Air Transport Association (D'Abszac, 2019), upwards of 8 billion by 2035 and of 16 billion by 2050, WHS can expect an impact on their visitation numbers. The aim of this article, through an econometric analysis of a sample of five selected sites around the world, is to raise awareness of the benefits that potential collaboration between stakeholders can bring, to develop a model to analyze the geographical interrelation between WHS and international airports and finally to extract conclusions for policy-makers within these two sectors.

The methodology employed in this research is cross-referencing official arrival and visitation data from both airports and WHS between 2009 and 2019. It includes the haversine formula comparing distances between international airports (DGAC, 2020) and WHS (Interactive map, 2020). For the purpose of this research, several regional tourism boards and airport CEOs were also consulted. The consensus from this consultation is that the majority of tourists intend to visit a WHS if it is located no more than 2 hours from the place they choose to visit. As distances by time are too varied according to several factors such as mode of transport, infrastructure, natural landscapes, and the research reported in this article is based on air transport, the option taken was to use air distance. As it was necessary to settle a benchmark, the distance variable for this research is fixed at 100 kilometers from an international airport which corresponds to a skyrocketing phenomenon of short trips of no more than a few days spent in a city, often involving visits most commonly known as city break tourism. Indeed, over the last decade, a new tourism trend has developed more especially in Europe. The main objective of the city breakers is to break the routine of daily life by discovering new places and a new culture for a weekend or a few days (Amadeus, 2018).

The existing literature does represent destination marketing, cultural marketing and macro-economic enablers of tourism and typology segmentation; however, after a review of available literature on the subject, it does not include the methodology and scope as presented in this article. Reinforcing our claim of introducing both a creative and innovative approach towards the issue.

Innovative in the sense that it is a first attempt to pose and begin to question this hypothesis. Creative, as we hope to open the door to further research by using this established and reproducible methodological process which can in turn be employed for other global sites extracted from the databases employed in this article.

\section{Literature review and hypotheses development}

This article attempts to answer some key questions such as:

Is there any connection between the levels of air travelers and world heritage sites? Knowing that a WHS is around $100 \mathrm{~km}$ from the city visited, is this a required premise for augmented tourism arrivals? Do airports and or tourism institutions need to collaborate in order to potentially grow the number of visitors to the nearest WHS?

The liberalization and deregulation of air transport is leading airlines to re-examine their tourism strategies as a whole new level of globalization, triggering a major upheaval as companies are generally abandoning their vertical integration and tourism diversification, and refocusing on activities linked directly with air transport. Airlines profit from increased efficiency derived from economies of scale, economies of scope and density economies. On the demand side, the passengers enjoy better range of available destinations, higher frequency of service and new business models, such as the entrance of low-cost carriers (LCC) to the EU market in the second half of the 1990s. Bieger and Wittmer (2016) 
note a correlation between total number of air travels and international tourism arrivals as air transport infrastructure has a major influence for many countries where tourism plays an important role in the local economy. The availability of low-cost air transportation has also fostered this environment since 1971, when Rolling King and Herb Kelleher created South-West airlines in the United States of America then followed by Ryanair in 1985 (Olipra, 2015). In a combined programming and econometric framework on twelve European airports, Button, Kramberger, Grobin, \& Rosie (2018) noted that the presence of low-cost carriers affects tourist-oriented airports'efficiency. 2019 saw a continued trend of increasing international tourist arrivals for the tenth consecutive year with more than 1,4 million arrivals equating to a 6\% increase from 2018 (UNWTO, 2020).

The UNWTO 2019 Annual Report estimates that tourism contributes to 10.4\% of global GDP, produces US\$1.7 trillion in total exports through direct, indirect and induced means, and creates 1 in 10 jobs. $58 \%$ of total arrivals were conducted through air transportation with leisure, recreation and holidays accounting for $56 \%$ of the purpose of visits in 2018 which represents an increase of $12 \%$ since 2000. In the same time, according to the UNWTO, 2018 totaled 1.4 billion international tourist arrivals which represents an increase by 6\% compared with 2017 figures and is clearly above the $3.7 \%$ growth registered in the global economy. Europe received 50.9\% of global arrivals with France remaining as the leading nation ahead of the United States, Spain, China and Italy in terms of total annual arrivals of 89.4 million in 2018. International tourism receipts in France alone reached US\$67 billion for 2018.

Overall direct growth in Travel \& Tourism (WTTC) throughout 2019 outpaced that of the global economy at $2.5 \%$ and outperformed the economy-wide growth for a ninth consecutive year as published by the World Tourism and Travel Council in its 2019 report. In the first ever UNWTO/ IPSOS Survey in January $2019,47 \%$ of respondents think "they live in cities with a high number of tourists". Over $50 \%$ consider that tourism has a positive impact in generating wealth and promoting cultural exchanges, and $49 \%$ feel there should be measures to improve tourism management (UNWTO, 2019).

\subsection{Role of international airports on World Heritage Sites}

It is important to understand the role of international airports on WHS before analyzing the evolution of both passenger, tourism traffic and its impacts on an economy. The 'Airports Council International (ACI) Europe Airport Traffic Report for 2017' includes 252 airports in total representing more than $88 \%$ of European air passenger traffic. Director General of ACI Europe, Olivier Jankovec noted that '2017 marks the best year for European airports since 2004, when air traffic was boosted by the accession of 10 countries to the EU - the single largest expansion of the bloc. That parallel is quite something when you consider the current climate includes Brexit and all its uncertainties. This performance comes on top of several years of dynamic growth and shows that demand for air transport keeps outperforming the economy and defying geopolitical risks - for now... '.

For the major International airports, Amsterdam-Schiphol's growth rate led the way $(+7.7 \%)$, confirming its 3rd position with 68.5 million passengers, behind Paris Charles de Gaulle (69.5 million passengers, $+5.4 \%)$. London-Heathrow remained the busiest European airport with 78 million passengers $(+3 \%)$. Frankfurt airport posted the second-best performance $(+6.1 \%, 64.5$ million passengers) and remained in its $4^{\text {th }}$ position, followed by Istanbul-Atatürk $(+5.9 \%, 63.9$ million passengers).

France alone has over 60 international airports including its overseas territories, with 10 international airports in Southern France alone servicing the UK, Ireland, Sweden, Norway, continental Europe, Canada and USA. The list of international airports in Southern France includes Nice, Toulon, Marseille, Avignon, Nimes, Montpellier, Beziers, Carcassonne, Perpignan and Toulouse (Go Languedoc, 2018). Huang, Yang and Tsau's (2012) research on the impact that WHS have on tourism levels reveals somewhat mixed results with some researchers citing only short-term positive impacts in terms of arrivals. Gonzales Santa-Cruz and Tomas Lopez-Guzman (2017) show that even though cultural and environmental endowments can have a positive effect on tourist destinations, the presence of UNESCO 
sites can have negative effects due to the expectations from tourism supply and demand as well as having adequate local policies in place to manage this traffic.

WHS belong to everyone and huge crowds flock into those sites year after year. With the expansion of air transport, few places have escaped the curiosity of visitors. WHS are recognized by the international community as among the world's most treasured and emblematic destinations. Even though the interaction between WHS and tourism has been both self-motivated and intimately interlinked since the early 1970s ( $\mathrm{Su}$ and Lin, 2014), some of the findings research challenge the idea of a positive relationship between WHS and airport levels, what hasn't been considered in the research concerning the relationship between international airports and WHS, is the impact that distances between these two sites have on the country's tourism arrivals. International passengers are considered as a reference in this research despite the fact that not all of them would consider visiting a WHS, even if it is within a $100 \mathrm{~km}$ air distance from an airport.

\subsection{Current academic discourses and debates}

Pertaining to the academic discourses or debates on the effect that distances between WHS and international airports have on tourist arrivals, nothing within the literature review has attempted to report on this approach. Apart from UNESCO published works and individual airports and/ or specific cities at a political level, it is difficult to find any scientific articles tackling this issue. To that end, this paper is an innovative research which aims to influence urban planners, stakeholders and practitioners within WHS and airports. However, in the current academic discourse there exists various conclusions regarding the effect that increasing tourist arrivals at WHS have on a city or country. Albeit the debates are founded on the various impact types such as socio-political, cultural, economic and climatic.

UNESCO states on their website (2020), "The World Heritage Convention is not only 'words on paper' but is above all a useful instrument for concrete action in preserving threatened sites and endangered species. By recognizing the Outstanding Universal Value of a site, States Parties commit to its preservation and strive to find solutions for its protection. If a site is inscribed on the List of World Heritage in Danger, the World Heritage Committee can take immediate action to address the situation and this has led to many successful restorations. The World Heritage Convention is also a very powerful tool to rally international attention and actions, through international safeguarding campaigns."

The Operational Guidelines for the Implementation of the World Heritage Convention is the main working tool on World Heritage. To be included on the World Heritage List, sites must be of outstanding universal value and meet at least one out of ten selection criteria which includes the following:

- to represent a masterpiece of human creative genius

- to exhibit an important interchange of human values on developments in architecture or technology, monumental arts, town-planning or landscape design

- to bear a unique or at least exceptional testimony to a cultural tradition or to a civilization which is living, or which has disappeared

- to contain superlative natural phenomena or areas of exceptional natural beauty and aesthetic importance

What appears constant for the last decade, (Farid, 2015) or (Massidda \& Mattana, 2013) is the findings on the affirmative relation between the presence of heritage sites and tourist arrivals when WHS are managed in a sustainable manner. Another aspect that is well researched and undisputed, is the trend of increasing total number of heritage sites globally, in-line with increases in tourist arrivals with many of these sites accounted for in Europe (Su, Lin, 2013). Influences of this increasing trend in tourist arrivals at heritage sites are attributed to various factors including accessibility of transport, namely air transport, technological innovations, augmented quality of life and social and political values that are credited to travelling (Cravidao, Nossa and al, 2018: 24). 


\section{Relevant literature}

The following literature review is based on publications that emphasize the various impacts on tourism arrivals around the world.

Vanblarcom \& Burc (2011) estimated a 6\% increase in tourist arrivals since UNESCO listing based on a study conducted on the Grand Pré Historic Site. International tourism levels, unlike many other sectors of the economy, don't seem to suffer as acutely from macro-economic driven determinants as other areas on the global arena. Even when the world was facing simultaneous global crisis' in the aviation and financial industries marked by travel-related security threats post-September 11, 2001, Indonesia saw a consistent increase in tourist arrivals of over 5\% "These numbers reflect the widely momentous change in how they are perceived by the Western-public-from a painful place of war and genocide to a luxurious cultural site in the course of but a few years" (Di Giovine, 2009).

Other Asian countries also experienced increases in arrivals such as Vietnam whose airports and heritage-listed sites enjoyed an annual rate increase of over 9\% between 1995 and 2005. Vietnam currently has eight heritage-listed sites (UNESCO, 2018) with five cultural, two natural and one mixed and witnessed a continued upward trend in 2017 with international tourist arrivals hitting 12.92 million (2019). Indonesia also boasts eight heritage-listed sites with four cultural and four natural sites and in 2019 saw international tourism arrivals increase to over sixteen million (Trading Economics, 2020). Despite Indonesia enjoying consistent increases in their visitation rate in 2019 with a total of 16.1 million foreign tourists, they did face difficulty in reaching their 2019 tourism arrivals target of 20 million. According to BPS data, nearly 10 million foreign tourists visited Indonesia by using airlines, followed by 4.1 million using sea transportation and 2.1 million using land transportation (Akhlas, 2020).

Factors affecting destination development include political and economic stability, security, governmental tourism policy, attractions and of course, accessibility (Henderson, 2006). Henderson and the stakeholders at Dubai International airport understood this by explaining, 'The history of tourism is closely tied to advances in transport and easy access by air is a prerequisite for any country seeking to be a leading international destination. Dubai aspires to be an air transport hub for the Middle and Far East and authorities are building an appropriate communications infrastructure. The civil aviation industry has progressed at speed and the airport is the sixteenth busiest measured by international passenger movements. There was a fourfold increase between 1991 and 2003 when an estimated 18 million were carried by 105 airlines serving 145 destinations, many of these customers of the duty-free shopping area where annual sales are amongst the highest in the world (Gulf News, 2004a)'.

Dubai International airport serves the United Arab Emirates as well as the international community and in 2019 remained for the sixth time in a row in the top 10 world's busiest airports in terms of total passengers of over 86.4 million as per the 2018 Airports Council International report (2018). The correlation between inaccessibility and low tourism arrivals at various sites around the world have been well documented (Shackley, 2020). Low tourism numbers equate to reduced dependence on strategic management requirements and less intervention.

On the other hand, sites that receive heightened levels of arrivals also face challenges regarding traffic congestion and other management issues. A noted obstacle includes these organizations working in competition, rather than collaboration, resulting in potential losses from the advantages that partnership can bring. This hypothesis is however based on shared values and the number of stakeholders involved (McKercher and du Cros, 2012). Notwithstanding these advantageous and negative impacts, WHS continue to generate strategic management issues concerning visitors and the local population. As demand increases for access to WHS, so does the importance of building strong collaborative partnerships with other tourism stakeholders such as airports. 


\section{Research methodology}

This article tackles the question of distance between both airports and WHS however it could also be interesting to cross check the results from another angle. Among different trip features (Mathieson and Wall, 1982). Such as trip cost/value, perceived risk and uncertainty of work, domestic pressures, trip duration, here 100 kilometer-trip distance from an international airport to a WH site has been chosen. The methods and tables used for the purpose of this research show the interdependent relationship between such distances and tourism arrivals throughout international airports and a selection of WHS in France, Australia, the United States of America and the United Arab Emirates.

The following issues in this paper will be presented insomuch as to draw conclusions and drive further research and collaboration within the connection between air visitors and WHS.

Relative to the most populated cities and urban tourism, it is shown that if a tourism site is less than 1 hour from a departure city then it becomes more appealing for visitors in terms of time and accessibility (Dunne, Flanagan and Buckley, 2010). This is the main criteria taken into consideration for this article, the distance between airport access and WHS. The article aims to raise awareness through a detailed analysis of the benefits of collaboration between airports and World Heritage sites.

The Trip Advisor TripBarometer (2019) which reports on insights into how travelers research and book their holidays stated that "different types of trips lead to a different emphasis on booking behavior" and concluded that "most trips are destination-led with most travelers beginning their visit research on a destination". It is interesting to note that the TripBarometer found that for those travelers who did not begin with researching the destination, $42 \%$ of the travelers reported that they began researching flights. The top traveler type among Tripadvisor users are city travelers just before beachgoers and cruisers. They are more likely than others to look for destinations where they can enjoy the history/ culture and also have some excitement and fun too.

City breaks are a twentieth century travel phenomena which are defined as short term holidays organized in an urban environment during short periods of time such as weekends and have developed, in part, due to the rise of low-cost transportation and reducing trend in extended-period holiday breaks (Kazakov and Nikolova, 2015). Dunne, Flanagan and Buckley (2007) state the various motivational forces of city break tourism arguing that "access to low-cost air transportation acts as both a destination determinant and the main purpose for taking a trip". Today, we are more aware of the importance of preserving areas of special interests for future generations. In today's multicultural society, with the impact of globalization and the homogenized and increasingly industrialized landscapes surrounding us every day, the idea of escaping to an unspoiled and culturally rich environment for a holiday is becoming more attractive. As Tourism continues to grow in both volume and importance as a global industry, it is vital that the world manages this growth in a sustainable manner. The research was intended to develop a systems model to analyze the geographical interrelation between World Heritage sites and international airports. And finally, the results from the research aims to extract conclusions for policy-makers within both World Heritage sites and international airports. This is why many questions including the following have arisen.

\section{Results and discussions}

Official updated data was collected concerning the number of airports globally (DGAC, 2020), a list of all Word Heritage sites within 100 kilometers measured by their longitude and latitude (UNESCO, 2018), and finally cross-referencing passenger arrival and visitation data using an Excel spreadsheet for comparative analysis. Four countries across four continents and five WHS were chosen for this article in order to represent a global perspective across both cultural and economic divides. Two sites in France along with one site in Australia, the United States of America and the United Arab Emirates.

Table 1 represents a cross-referenced sample of international airports within 100 kilometers from a WHS with reference points across all airports and WHS in the initial database extract revealing a total of 12399 possible links around the world. The table includes airport code, name and country, UNESCO reference number, listing date, country and distance between the WHS and airport. 
Tourism arrivals at selected airports and World Heritage sites were then collected and a comparative analysis conducted to measure fluctuations both one year before the UNESCO listing date and statistics from 2018.

In order to ensure access to reliable data, only WHS listings between 2010 and 2018 were considered for this article, however the initial database extract includes all airports and WHS sites as per the DGAC, ICAO and UNESCO databases.

Table 1: Example of primary cross-reference of WHS $<100 \mathrm{kms}$ from international airports

\begin{tabular}{|l|l|l|l|l|l|l|l|}
\hline Airport Code & Airport Name & Country & UNESCO ID & $\begin{array}{l}\text { World heritage } \\
\text { Site }\end{array}$ & $\begin{array}{l}\text { WHS } \\
\text { Country }\end{array}$ & $\begin{array}{l}\text { UNESCO } \\
\text { Listing date }\end{array}$ & $\begin{array}{l}\text { Distance } \\
\text { Airport - WHS (kms) }\end{array}$ \\
\hline AGGR & Rennell & $\begin{array}{l}\text { Solomon } \\
\text { Islands }\end{array}$ & 854 & East Rennell & $\begin{array}{l}\text { Solomon } \\
\text { Islands }\end{array}$ & 1988 & 34.236083 \\
\hline BGBW & Narsarsuaq & Denmark & 1536 & Kujataa Greenlan & Denmark & 2017 & 9.026826 \\
\hline BIKF & Keflavik & Iceland & 1152 & $\begin{array}{l}\text { Thingvellir Nation } \\
\text { Park }\end{array}$ & Iceland & 2004 & 82.186623 \\
\hline BKPR & Pristina & Kosovo & 724 & $\begin{array}{l}\text { Medieval } \\
\text { Monuments Koso }\end{array}$ & Serbia & 2004 & 64.177107 \\
\hline DAAA & Alger (ACC & Algeria & 565 & Kashbah of Algie & Algeria & 1992 & 17.614516 \\
\hline
\end{tabular}

Source: cross-referenced from DGAC, ICAO and UNESCO databases of 2019.

Table 2 refines the scope to compare international airport arrivals with World Heritage site visits for the year 2017 at five chosen sites.

The five final WHS in this article were chosen out of the many options in the databases retrieved due to their 100-kilometer proximity to an international airport, UNESCO inscription date since 2010 and four countries encompassing four continents to allow for cultural differences in the statistical analysis. Another parameter in the selection of WHS was made according to the disclosure of detailed and accessible data with an understanding that not every WHS reports on visitation levels. Choosing sites in different continents was crucial in testing geographical and cultural variances in the analysis.

Table 2 includes the same fields and data in Table 1 with the addition of fields for airport arrivals in 2017 and WHS visits for the same year.

Table 2: International airport arrivals ${ }^{1}$ compared to WHS visits $\mathbf{2 0 1 7}^{2}$ (millions)

\begin{tabular}{|l|l|l|l|l|l|l|}
\hline $\begin{array}{l}\text { Airport } \\
\text { Name }\end{array}$ & Country & $\begin{array}{l}\text { UNESCO } \\
\text { Site }\end{array}$ & $\begin{array}{l}\text { UNESCO } \\
\text { listing date }\end{array}$ & $\begin{array}{l}\text { Distance } \\
\text { Airport } \\
\text { WHS (kms) }\end{array}$ & $\begin{array}{l}\text { Airport } \\
\text { arrivals }\end{array}$ & $\begin{array}{l}\text { WHS visits } \\
2017 \\
\text { (millions) }\end{array}$ \\
\hline
\end{tabular}

1 Air passenger arrivals 2017: (1.) Toulouse-Blagnac Airport 2014 review http://www.toulouse.aeroport.fr/sites/default/files/contrib/societe/lasociete/bilan_2014_en_v03_0.pdf. Accessed 22 November 2018. (2.) Montpellier Méditerranée Airport 2017 statistics https://montpellier-airport.com/ammcompany/montpellier-mediterranee-airport/statistics-montpellier-airport/. Accessed 22 November 2018. (3.) Sydney (Kingsford Smith Airport). Airport traffic data. Australian Bureau of Infrastructure, Transport and Regional Economics. https://bitre.gov.au/publications/ongoing/airport_traffic_data.aspx . Accessed 28 November 2018. (4.) San Antonio International Airport. City of San Antonio Aviation Department. "Statistics - San Antonio International Airport 2017. https://www.sanantonio.gov/Aviation/Financial-Information-Statistics\#33782532-2017- . Accessed 28 November 2018. (5.) Al Ain International airport Statistical Year Book of Abu Dhabi 2018, 97 https://www.scad.gov.abudhabi/Release\%20Documents/SYB_2018_EN_9Sep.pdf . Accessed 28 November 2018.

${ }^{2}$ WHS visits 2017: (1.) Albi - 2016 Albi Office de tourisme: Etats généraux de janvier 2017 (2.) Pont d'Arc - 2016 Ardeche tourisme http://pro.ardeche-guide.com/la-caverne-du-pont-d-arc. Accessed 22 November 2018. (3.) Convict sites - Historic House Trust, Sydney Living Museums Annual Report 2016-2017. (4.) San Antonio Missions (The Alamo) - Texas Land Commission. http://savethealamo.com/governance.html . Accessed 28 November 2018. (5.) Cultural sites of Al Ain Department of Culture and Tourism - Abu Dhabi: statistical yearbook Abu Dhabi 2017 (Regional visitors). 


\begin{tabular}{|l|l|l|l|l|l|l|}
\hline & & & & & $\begin{array}{l}\mathbf{2 0 1 7} \\
\text { (millions) }\end{array}$ & \\
\hline Toulouse & France & $\begin{array}{l}\text { Episcopal } \\
\text { City of Albi }\end{array}$ & 2010 & 69.81138 & 9.2 & $1.5(1)$ \\
\hline $\begin{array}{l}\text { Montpellier } \\
\text { MED }\end{array}$ & France & Pont d'Arc & 2014 & 96.92199 & 1.8 & $0.510(3)$ \\
\hline $\begin{array}{l}\text { Sydney Int } \\
\text { (Mascot) }\end{array}$ & Australia & $\begin{array}{l}\text { Hyde Parks } \\
\text { Barracks } \\
\text { Museum }\end{array}$ & 2010 & 65.84519 & 8.06 & $0.177(5)$ \\
\hline $\begin{array}{l}\text { San } \\
\text { Antonio Int }\end{array}$ & $\begin{array}{l}\text { United } \\
\text { States }\end{array}$ & The Alamo & 2015 & 22.47607 & $9.06(7)$ & 1.7 \\
\hline Al Ain Int & $\begin{array}{l}\text { United } \\
\text { Arab } \\
\text { Emirates }\end{array}$ & $\begin{array}{l}\text { Cultural } \\
\text { Sites of Al } \\
\text { Ain }\end{array}$ & 2011 & 29.22019 & 0.062 & 0.45 \\
\hline
\end{tabular}

Source: Individual airport sites and individual UNESCO listed sites

(1.) 2016 results Albi Tourism Office (3.) 2016 results Ardeche Tourism Office (5.) 2016 results Sydney Living Museums Annual Report. (7.) Total passengers San Antonio International.

Table 3 is designed to determine fluctuations in tourism arrivals before and after being listed on UNESCO, therefore table 3 presents the cross-referenced statistics of WHS visits and passenger levels.

Reliable data proved difficult to find regarding tourist arrivals across all WHS both before and after heritage listing, and as a result, the tables represents five of the most recently inscribed sites by UNESCO across the world where tourism data was available. Table 3 includes the same fields and data as in Table 1 and 2, with the addition of 2 fields for WHS visitation levels and airport arrivals dated one year before UNESCO listing of the cited WHS.

Table 3: Comparative analysis - air passenger arrivals and $\underline{\text { WHS visitation levels }}^{3}$ one year before UNESCO inscription and 2017 (millions)

\begin{tabular}{|l|l|l|l|l|l|}
\hline Airport & UNESCO site & $\begin{array}{l}\text { Airport } \\
\text { arrivals 2017 } \\
\text { (millions) }\end{array}$ & $\begin{array}{l}\text { WHS Visits } \\
\mathbf{2 0 1 7} \\
\text { (millions) }\end{array}$ & $\begin{array}{l}\text { Airport } \\
\text { arrivals } \\
\text { before } \\
\text { UNESCO } \\
\text { listing } \\
\text { (millions) }\end{array}$ & $\begin{array}{l}\text { WHS visitors } \\
\text { before } \\
\text { UNESCO } \\
\text { listing } \\
\text { (millions) }\end{array}$ \\
\hline Toulouse & $\begin{array}{l}\text { Episcopal } \\
\text { City of Albi }\end{array}$ & 9.2 & $1.5(1)$ & 6.3 & $0.8(2)$ \\
\hline Montpellier & Pont d'Arc & 1.8 & $0.510(3)$ & 1.4 & $0.4(4)$ \\
\hline Sydney Int & $\begin{array}{l}\text { Hyde Parks } \\
\text { Barracks } \\
\text { Museum }\end{array}$ & 8.06 & $0.117(5)$ & 5.37 & $0.066(6)$ \\
\hline $\begin{array}{l}\text { San Antonio } \\
\text { Int }\end{array}$ & The Alamo & $9.06(7)$ & 1.7 & 8.37 & $1.47(8)$ \\
\hline
\end{tabular}

${ }^{3}$ WHS visits (1.) Albi - CCI OCCITANIE - OBS ECO edition 2011.Page 10. Accessed 22 November 2018. (2.) Pont d'Arc - Press dossier 2014 Region Rhone-Alpes. Accessed 22 November 2018. (3.) Hyde Park Barracks Museum - Living Museums annual report 2009-2010 https://sydneylivingmuseums.com.au/sites/default/files/2009-2010-Annual-Report.pdf . Accessed 22 November 2018. (4.) The Alamo - Texas General land Office Report 2014. (5.) Cultural sites of Al Ain Department of Culture and Tourism - Abu Dhabi, Statistical yearbook Abu Dhabi 2011 (regional visitors) 


\begin{tabular}{|l|l|l|l|l|l|}
\hline Al Ain Int & $\begin{array}{l}\text { Cultural Sites } \\
\text { of Al Ain }\end{array}$ & 0.062 & 0.45 & 0.037 & 0.39 \\
\hline
\end{tabular}

Source: Individual airport sites and individual UNESCO listed sites

(2.) Albi Tourism Office «only Cathédrale Sainte-Cécile, Musée Toulouse-Lautrec, Promenades en gabarres ». (4.) Press release 2014 Region Rhone Alpes. (6.) Sydney Living Museums Annual Report 2009. (8.) Save the Alamo “Texas Land Commission”.

To answer our main issue, the statistics of worldwide sites help us to draw some possible answers with the statistical analysis allowing the measurement of fluctuations in arrivals at sites across the globe. The methodology of cross-referencing tourism arrivals data for both airports and WHS using their geographic coordinates intends to conceptualize a possible process in targeting segments of tourism and in this case, specifically for short stays or city breaks. The statistics help to start an innovative approach towards marketing and communication between airports and tourism stakeholders around the world. It could be cost-effective and furthermore, local communities can be involved in the process. Acknowledging the positive impact of an international airport's proximity to a WHS can prove profitable at different scales and economic levels. It is understood upon researching and writing this article that there are other factors affecting the causation of tourism arrivals and not simply the geographical location of airports. Direct, indirect and induced impacts include geopolitical circumstances, socio-cultural factors, financial situations, marketing strategies in place, the ecological environment, reputation of the country and world heritage site, and technological advancements; these facets among others all play a deciding role in affecting tourism levels at World Heritage sites and tourism in general.

This article is founded on the basis that the geographical positioning of international airports in conjunction with a WHS must also be considered as important as the above, well-documented and published factors within the related literature.

\section{Comparative analysis of five WHS}

The results from the comparative analysis between five WHS and International airports across France, with two sites, and one in Australia, the USA and the United Arab Emirates reveal an overall increase in levels of both air passenger arrivals and tourism arrivals at the sites after inscription by UNESCO.

\section{- Montpellier-Méditerranée Airport and Pont d'Arc (France)}

The Montpellier-Méditerranée Airport and Pont d'Arc WHS was chosen for different reasons. Firstly, it received its inscription as a World Heritage-listed site by UNESCO in 2014 and is referenced as 1426 under UNESCO's listing. Secondly, detailed statistics on the number of visitors were available before and after the inscription it fell within the methodology's 100-kilometer distance threshold.

The decorated cave of Pont d'Arc, known as Grotte Chauvet-Pont d'Arc in the Ardèche department of France.

It is famous for having some of the earliest known paintings which have been carbon-dated back to the Aurignacian period (30,000 to 32,000 years BP) (UNESCO World Heritage List, 2018).

Pont d'Arc reported estimated tourism arrivals in 2013, one year before UNESCO listing, at approximately 400,000 (Rhône-Alpes Tourism, 2014). In 2016, the site received over 500,000 visitors, $11 \%$ of which were international tourists with more than 24,000 guided visits provided by the team on site (Région Auvergne-Rhône-Alpes, 2017) ${ }^{4}$. Within two years of heritage listing by UNESCO the site had experienced a $20 \%$ increase in overall visits attracting 510,000 visitors.

Montpellier-Méditerranée Airport was opened in 1946 and is located 7km from Montpellier in Mauguio, in the Hérault Department in France and 96.92 kilometers from Pont

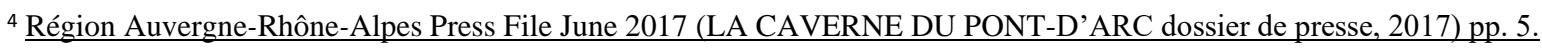


d'Arc ${ }^{5}$. In 2013, one year before Pont d'Arc's heritage listing, Montpellier-Méditerranée Airport reported total arrivals at 1.42 million passengers comprising 94,009 international visitors (AMM Company, 2014). By contrast in 2017, the airport enjoyed increased arrivals of both total and foreign visitors to the tune of 1.85 million and 209,507 respectively seeing and overall increase of 55\% for international traffic and 23\% for total arrivals within four years (AMM, 2017).

Fig. 1: Montpellier-Méditerranée Airport and Pont d'Arc passenger and visitation evolution

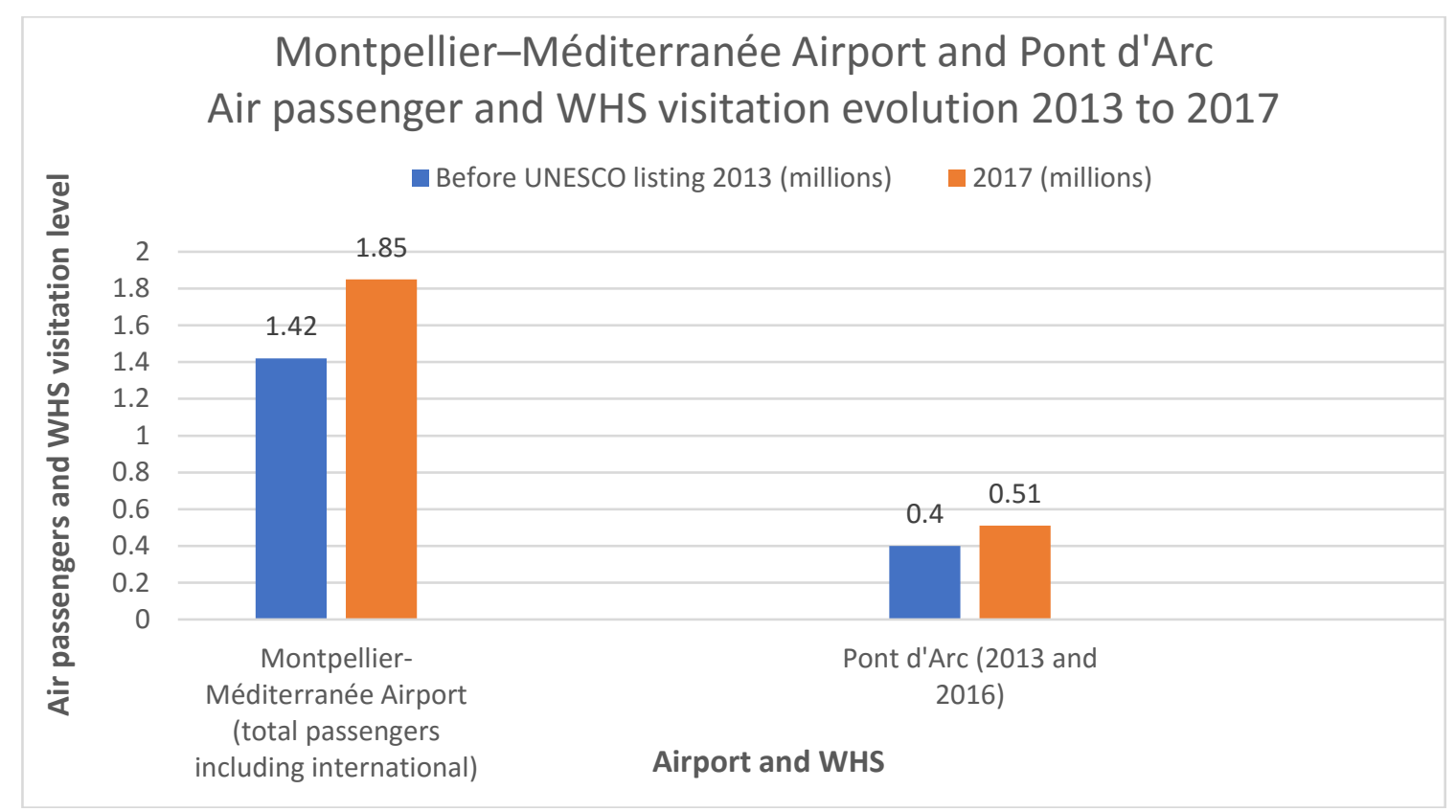

Source: compiled data from different official international statistical sites

\section{- Toulouse-Blagnac Airport and the Episcopal city of Albi (France)}

Albi is a city based in the south-western department Tarn and as described by UNESCO..." reflects the culmination of a medieval architectural and urban ensemble". The Episcopal city of Albi boasts many monuments and factor endowments including cathedrals, churches, museums among a medieval landscape that has been cited as both authentic and well preserved and is listed under UNESCO as reference 1337 (UNESCO, 2018).

The city of Albi's tourism has evolved tremendously over the years with 2009 seeing 819,269 visitors enjoying at least two of the offers on hand in the city; that being the Cathédrale Sainte-Cécile and the Musée Toulouse-Lautrec. All this just one year before the city was listed by UNESCO as a World Heritage site (OBS ECO, 2011). In 2016, the Episcopal city of Albi welcomed 1.5 million tourists in total, witnessing a $45 \%$ increase in traffic within less than a decade. Most visited sites once again included the Cathédrale Sainte-Cécile and the Musée Toulouse-Lautrec in the centre of the city totaling 1.08 million visitors for the two sites (CCI, 2017). Within nine years the city's two famous sites experienced a $25 \%$ increase in visitors.

Toulouse is the capital of both the department Haute Garonne and the region of Occitanie in southwestern France.

Situated 69.8 kilometers from the city of Albi (Table 3), Toulouse-Blagnac airport provides an international link to the south-west of France from 50 destinations within France and around the world (Aéroport Toulouse-Blagnac, 2018). One year before the city of Albi was listed on UNESCO's World

${ }^{5}$ Service de l'information Aéronautique (SIA Aviation civile) at https://www.sia.aviation-civile.gouv.fr/ . Accessed 23 November 2018. 
heritage list, Toulouse-Blagnac airport reported 6.28 million passengers for the year 2009 (Aéroport Toulouse-Blagnac, 2014). In 2017, the airport profited from a $14.6 \%$ year on year increase reporting 9.2 million passengers in total. A $32 \%$ increase in passenger traffic within ten years.

Fig. 2: Toulouse-Blagnac Airport and the Episcopal city of Albi passenger and visitation evolution

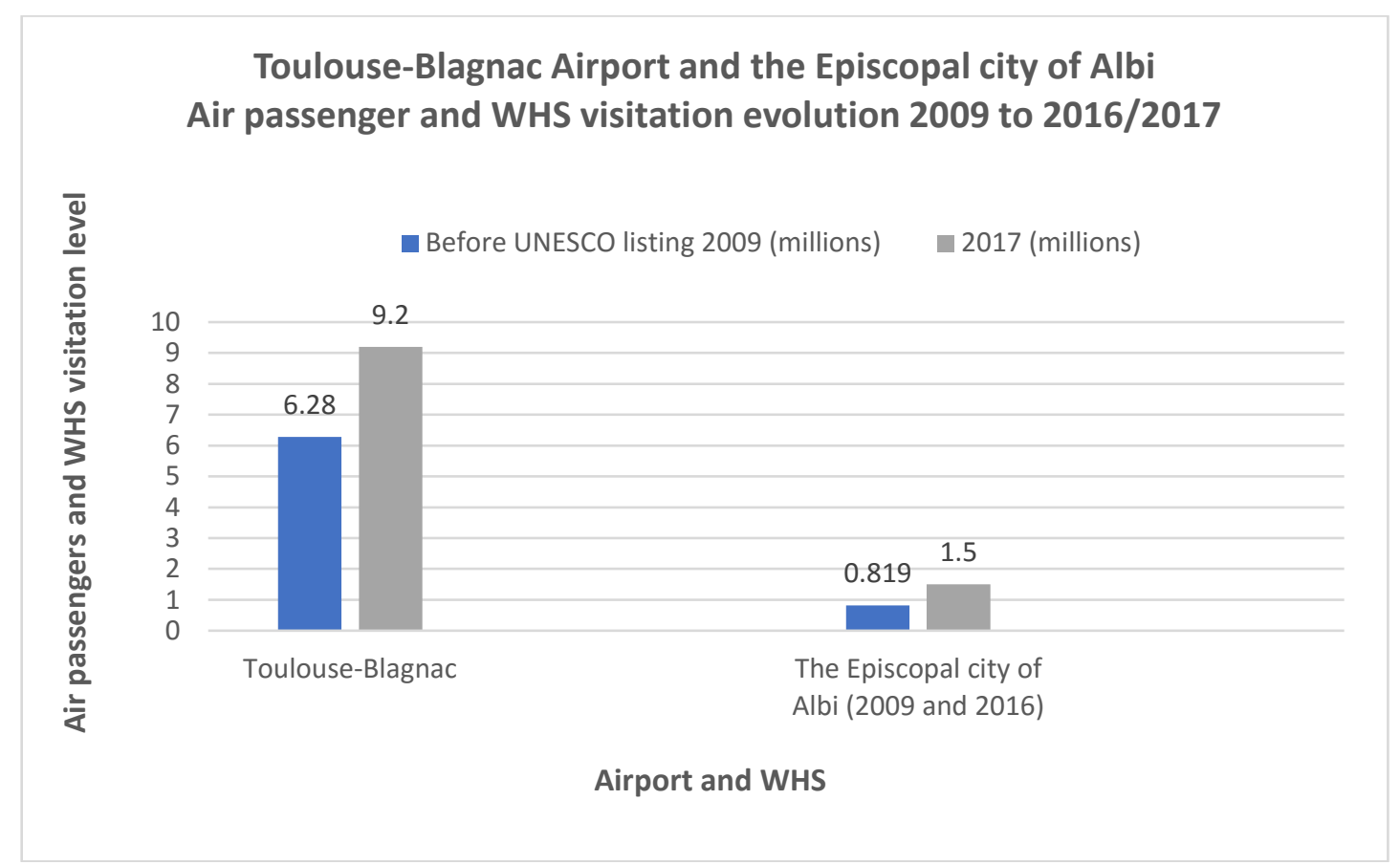

Source: compiled data from different official international statistical sites

\section{- Sydney Airport and the Hyde Park Barracks Museum (Australia)}

The Hyde Park Barracks Museum was constructed by convict labor between 1817 and 1819 and hosted more than 50,000 convicts between 1819 and 1848. By 1848 the barracks served as an immigration depot and asylum for destitute women. Later, the structure was converted to governmental offices. Conservation began in 1979 and the barracks opened in 1984 as a museum (Sydney Living Museums, 2018). The Barracks are one of eleven selected penal sites in Australia listed by UNESCO and are jointly referenced as 1306 .

One year before listing in 2010 by UNESCO the Barracks Museum saw visitor attendance levels at 66,000 in 2009 (Table 3). The Sydney Living Museums Annual Report 2016-2017 presented visitor numbers at 117,000 marking a $43 \%$ increase in the visitation rate within 8 years of heritage listing (Historic Houses Trust of NSW, 2018). Kingsford Smith Airport in Sydney Australia is located 8 kilometers from the city center and is owned by the Sydney Airport Group. The airport is located 12 kilometers from the Museum however it is geolocated 66 kilometers from the furthest heritage-listed site within the group of Convict Sites in Sydney. Kingsford Smith airport serviced 8.06 million inbound international arrivals in 2017 and 5.37 million in 2009, one year before heritage listing of the Australian Convict Sites and proves a 33\% increase in international arrivals to Sydney (Commonwealth of Australia, 2018). 
Fig. 3: Sydney Airport and the Hyde Park Barracks Museum Air passenger and WHS visitation evolution

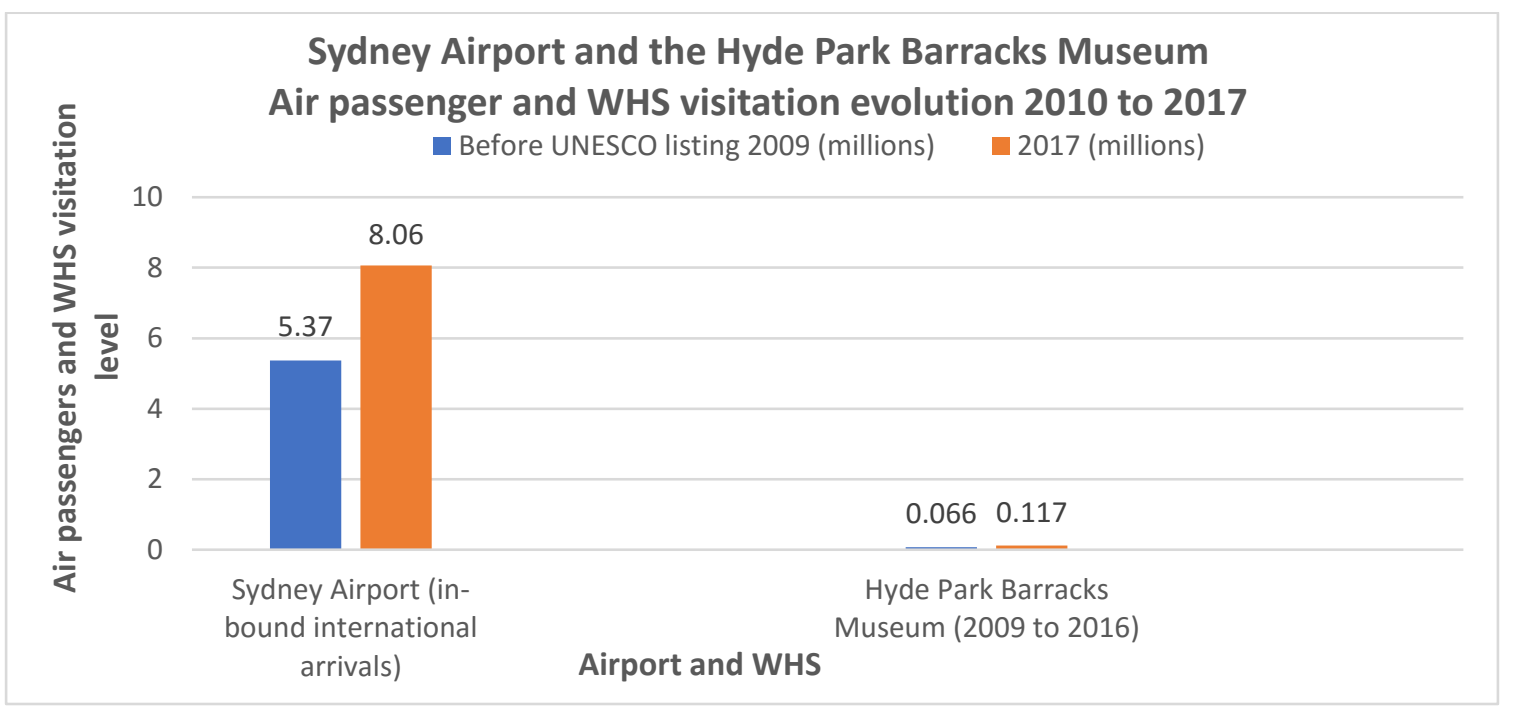

Source: compiled data from different official international statistical sites

\section{- San Antonio International Airport and The Alamo (USA)}

As per the National Park Service's mission on its website, "San Antonio National Historical Park protects, preserves, restores, and interprets four Spanish Colonial missions and their cultural landscape features, established along the upper San Antonio River. Through resource management, preservation, and public outreach, the National Park Service and its partners preserves this park for the education and enjoyment of this and future generations. " 6

The property consists of five frontier mission complexes, a ranch south of the site and is referenced by UNESCO as 1466 on the heritage list. UNESCO states, "The complexes were built by Franciscan missionaries in the 18th century and illustrate the Spanish Crown's efforts to colonize, evangelize and defend the northern frontier of New Spain. "7 The Texas Land Commission reports that Mission Valero, commonly known as The Alamo, catered to 1.47 million visitors in 2013, 2 years before gaining listing from UNESCO, and reported 1.7 million visitors in 2017 gaining and increase of $13.6 \%$ since before listing. San Antonio International Airport was founded in 1941, opened in July 1942 as Alamo Field and was used by the United States Army Air Forces as a training base. The airport is located in Uptown Central San Antonio, about 23 kilometers north of Downtown and The Alamo. The airport received 8.37 million total passengers one year before UNESCO listing in 2014, and 9.06 million total passengers throughout 2017 resulting in a $7.6 \%$ overall passenger increase in three years. ${ }^{8}$

\footnotetext{
${ }^{6}$ US Department of the Interior (2018). National Park Service at https://www.nps.gov/saan/index.htm . Accessed 28 November 2018.

7 UNESCO (2018). World Heritage List "San Antonio Missions" at https://whc.unesco.org/en/list/1466 . Accessed 28 November 2018

${ }^{8}$ City of San Antonio Aviation Department (2018). Statistics - San Antonio International Airport 2014 \& 2017
} 
Fig. 4: San Antonio International Airport and The Alamo Air passenger and WHS visitation evolution

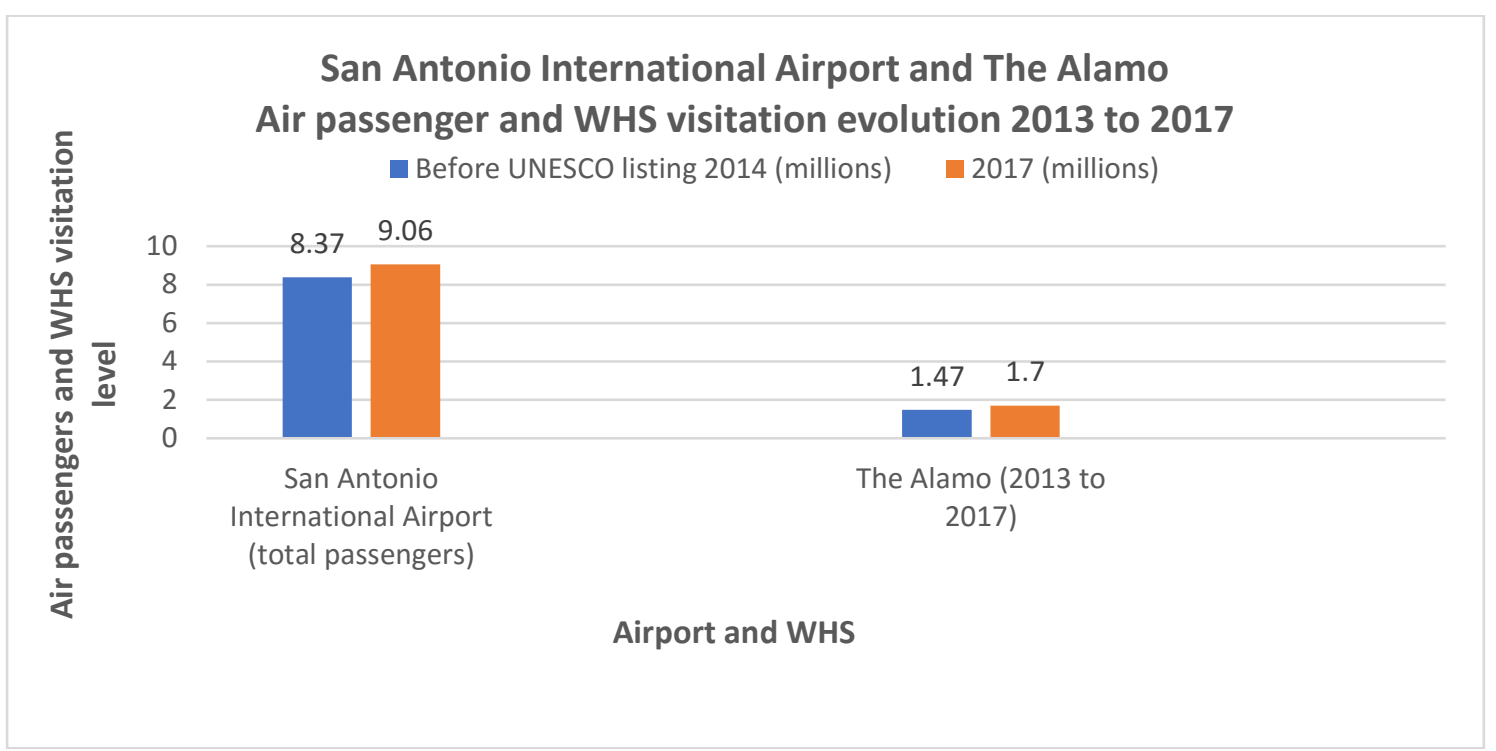

Source: compiled data from different official international statistical sites

\section{- Al Ain International airport and the Cultural Sites of Al Ain (UAE)}

The Cultural sites of Al Ain in the United Arab Emirates and include Hafit, Hili, Bidaa Bint Saud and Oases Areas and consists of a landmass spanning 4,945.45 hectares. A serial property listed by UNESCO in 2011 as reference 1343, UNESCO describes the sites as "a testament to sedentary human occupation of a desert region since the Neolithic period with vestiges of many prehistoric cultures... The property provides important testimony to the transition of cultures in the region from hunting and gathering to sedentarization." "9

Visitor numbers to the sites prior to heritage listing totalled 390,000 in 2010 and increased to an estimated 450,000 in 2017 as per Abu Dhabi's Department of Culture and statistical yearbook reports in 2011 and 2018. This showed a visitor increase of $13 \%$ over the nine-year period ${ }^{10}$.

Inaugurated in 1994, Al Ain International Airport is Abu Dhabi's second international airport located 18 kilometers from Al Ain City and approximately 29 kilometers from the cultural sites. The airport received 37,000 international passenger arrivals in 2009 and 62,000 in 2016 showing an overall increase of $40 \%$ in international arrivals alone ${ }^{11}$.

\footnotetext{
9 UNESCO. (2018). World Heritage List "Cultural sites of Al Ain" at http://whc.unesco.org/en/list/1343 . Accessed 28 November 2018.

${ }^{10}$ Department of Culture and Tourism - Abu Dhabi. Statistical yearbook Abu Dhabi 2017

${ }^{11}$ Abu Dhabi airport annual report. "International arrivals 2017".
} 
Fig. 5: Al Ain International airport and the Cultural Sites of Al Ain Air passenger and WHS visitation evolution

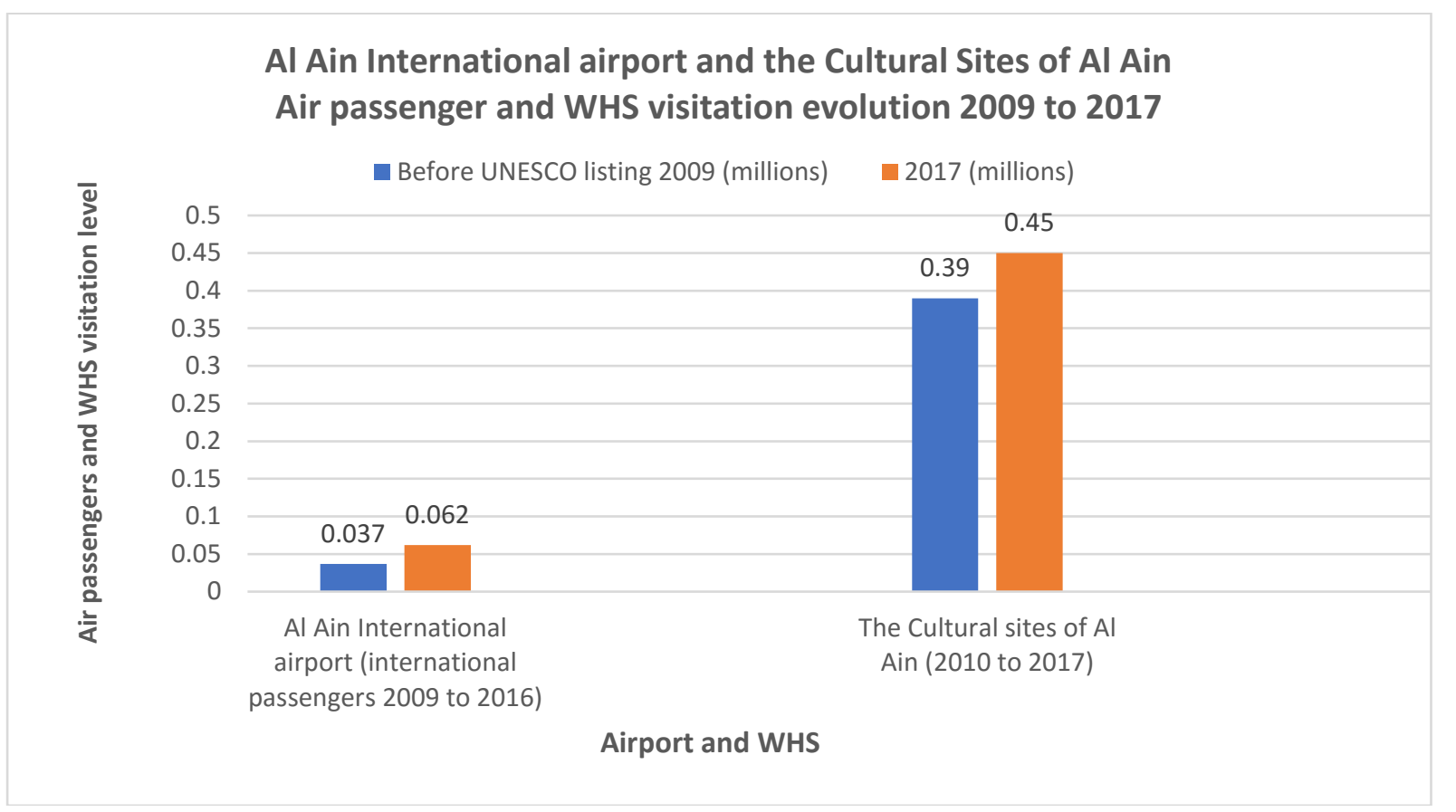

Source: compiled data from different official international statistical sites

\section{Global evolution of passenger and visitation levels at five airports and WHS}

The following charts highlight the positive impact that UNESCO listing has on a sample of five UNESCO sites around the world. As per the 2019 UNWTO and ISPOS global survey on the perception of residents towards city tourism, results from the online survey in 15 countries and out of a sample of 12,000 shows $71 \%$ of the respondents are in favor of creating experiences and attractions that benefit both residents and visitors. This is equally confirmed in the key results below.

\section{Evolution of passenger arrivals before and after World Heritage site listing}

It was interesting to extract from the official crossed data, the number of tourists via air visiting urban cities before and after inscription of WHS. The minimum increase among the five sites is at San Antonio International Airport registering an increase of 7.6\% between 2016 and 2017. However, it is also worth noting the recent promotion of the San Antonio WHS. The 2017 annual roadmap of Visit San Antonio, a new public-private non-profit organization/ company in charge of promoting the destination at an international level, noticed increased visits to World Heritage Missions content of more than 245 percent. Results from marketing towards domestic and international visitors could have an even larger impact in the following years.

As for the other cities, the number of international arrivals rose by more than $30 \%$ and even more than double in Montpellier. 
Fig. 6: Evolution of airport arrivals before and after heritage listing date

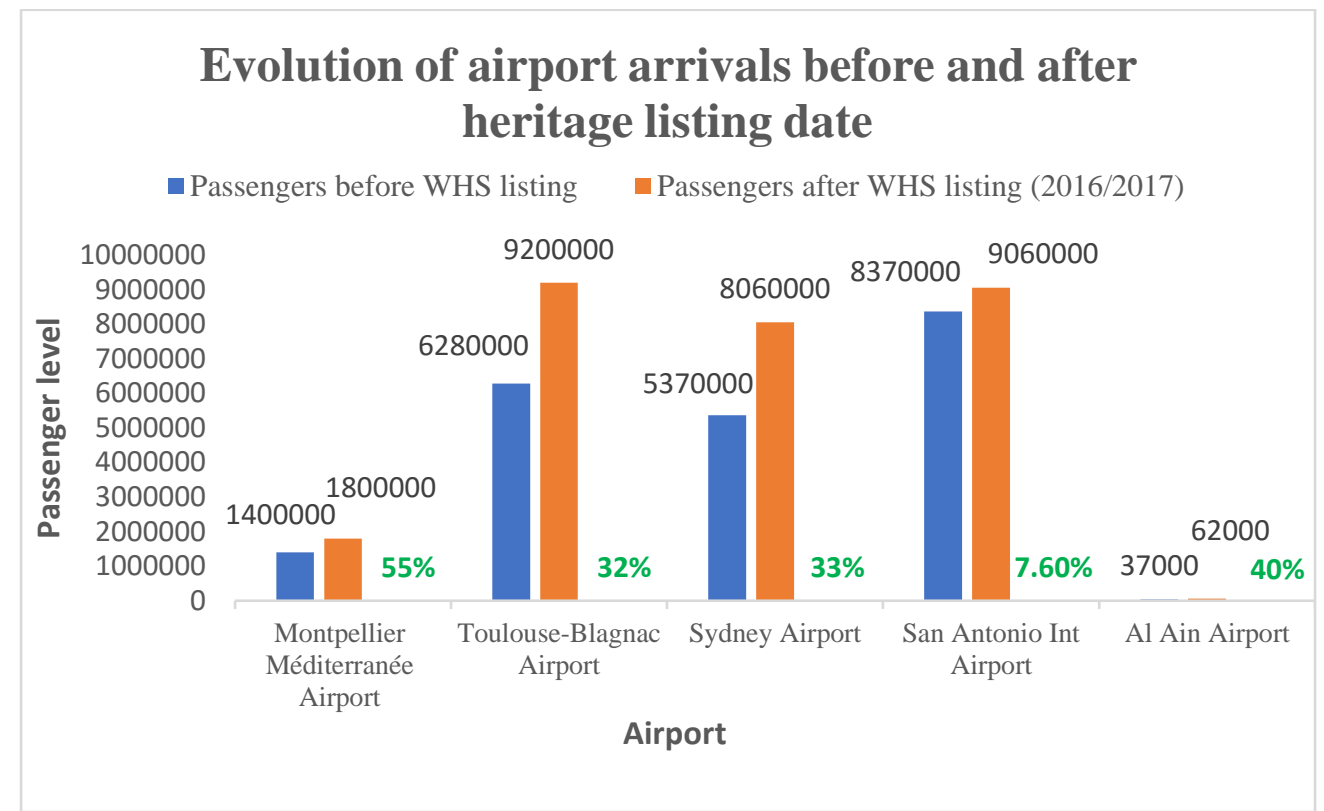

Source: compiled data from different official international statistical sites

\section{Evolution of WHS visitation levels before and after World Heritage site listing}

This chart gives a detailed evolution of visitors in cultural, historical and tangible sites before and after the inscription by UNESCO. All sites showed augmented levels of visitation levels with Albi and the Hyde Park Barracks showing the highest increase at $47 \%$ and $44 \%$ respectively. The Cultural sites of $\mathrm{Al}$ Ain and the Alamo proving the smallest increase at $13 \%$.

Fig. 7: Evolution of WHS visits before and after heritage listing date

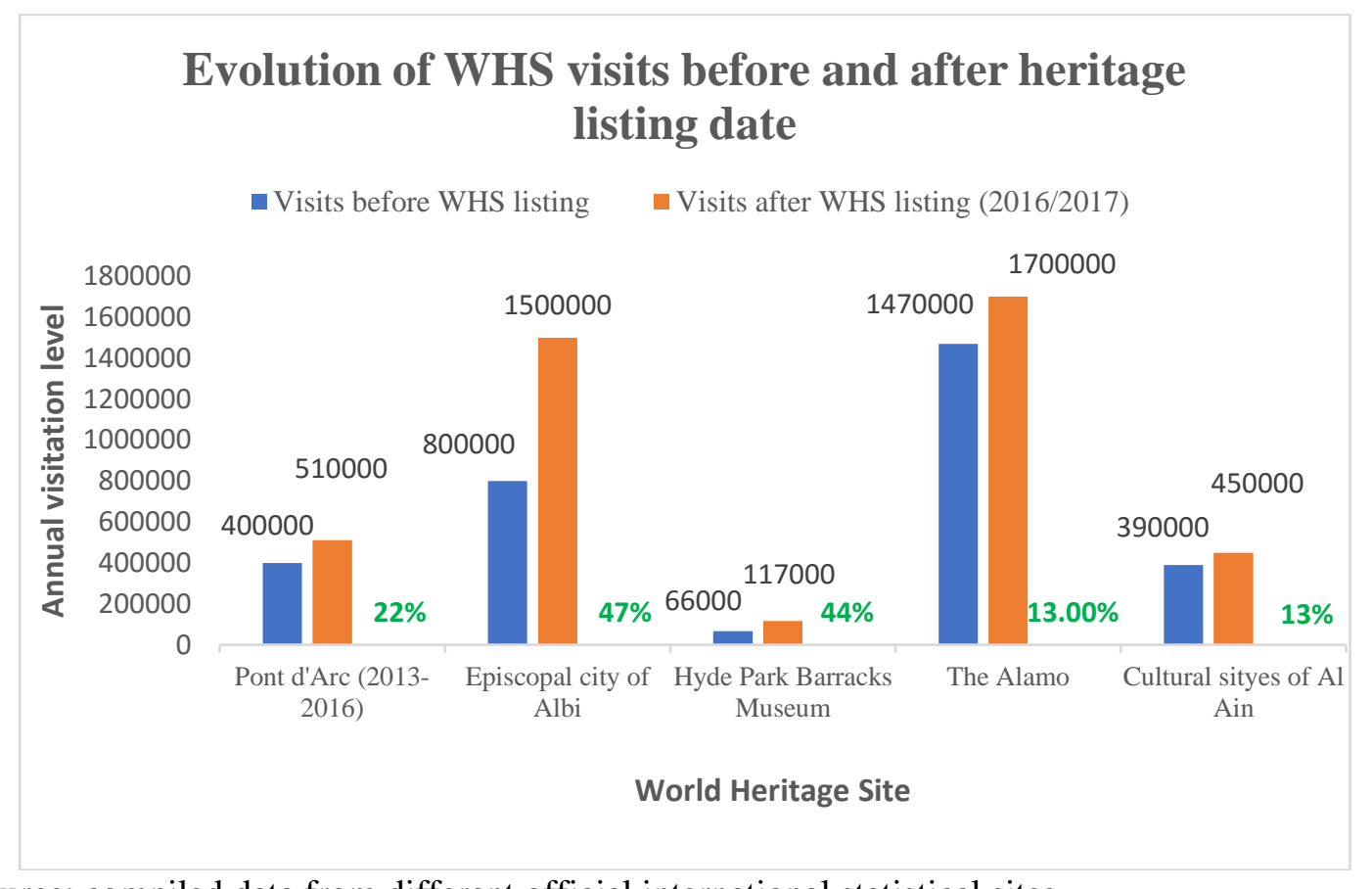

Source: compiled data from different official international statistical sites 


\section{Passenger and visitation averages}

The following chart 4.3 represents the statistical average results for both air passenger and visitation increase. The cumulative moving average shows the average increase over the period between one year before UNESCO listing and that of 2017 (2016 in some marked cases where data was either not reliable or found). The mode of averages is presented in order to show repetition within the dataset of averages while the range allows us to understand the amount of dispersion in the data.

As presented in chart 4.3 for passenger arrivals at the five airports studied, a cumulative moving average increase of a $33.52 \%$ was found between the years 2009 and 2017 with a range of the data set equating to $47.4 \%$. No mode was found within the scope of the airports. Montpellier saw the largest percentage increase of 55\% whereas San Antonio International witnessed the smallest at a rate of 7.6\%. All five airports studied saw an increase of passenger arrivals within both the time period and scope of this research.

For the five global WHS sites studied and presented in chart 4.3, a cumulative moving average increase in the visitation rate of a $27.8 \%$ was found between the years 2009 and 2017 with a range of $34 \%$ and a mode of $13 \%$. The Episcopal city of Albi saw the largest percentage increase of $47 \%$ whereas both the Alamo and the Cultural sites of Al Ain witnessed the smallest at 13\%. All five sites studied saw an increase in visitation rates.

Fig. 7: International Passenger and visitation increase averages 2009 to 2018 worldwide

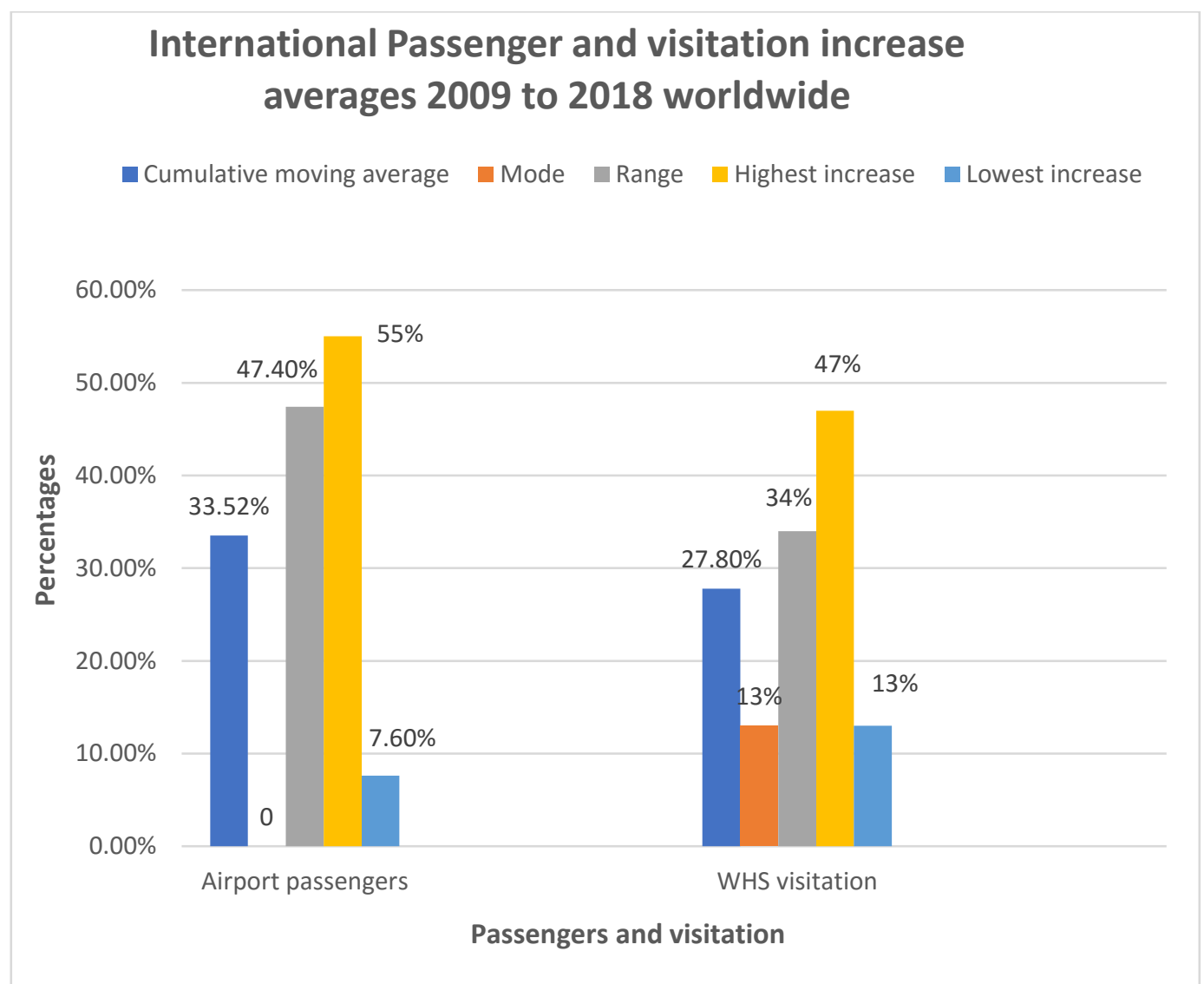

Source: calculations from compiled data retrieved from different official international statistical sites 


\section{Conclusion}

In this paper we investigate the positive relationship between passenger arrivals at international airports and WHS visitation levels on a global scale using panel data from four countries between 2009 and 2017 both before and after UNESCO listing of WHS. The results and findings above indicate that there is a positive relationship, correlation and or causation, between increased arrivals at international airports and World Heritage site visits however the analysis and the methodology do not suggest that one ultimately causes the other. The conclusion is based on three identified factors within the scope of the research. Firstly, that the World heritage site is located no more than 100 kilometers from an international airport to allow for city break tourism. Secondly, that the World heritage site was listed during or after 2010 and thirdly, there is reliable economic data available on both WHS visits and airport arrivals, before and after heritage listing by UNESCO. No regressive levels of visits or arrivals after UNESCO listing were found among the WHS and airports studied in this article which supports the notion that international airports and WHS should collaborate to sustain future tourism levels.

\section{Limitation and study forward}

The limitations of this methodology include sourcing accessible and reliable data on tourism visitation levels at certain WHS. Certain environmental WHS have difficulty in reporting on actual visits and the reliability of some tourism organizations to report real data as opposed to the marketing of promotional material poses a threat to data integrity. Considering the measurement of distances between both WHS and airports employed the Haversine method, the methodology could also include using innovative digital tools such as Google Maps to determine these distances via road routes.

It is suggested that the research questions raised in this article are mostly incomplete and ignore other factors affecting both WHS visits and International airport arrivals as previously stated.

What is the geographical distance threshold between WHS and airports when negative economic impacts begin to occur? What is the impact that distance has on tourism sites that are not listed by UNESCO? These and other questions could be tackled with a different approach towards geographical distances, a variety of other tourism sites and allow for any of the 12399 possible combinations in the initial data extract to further test the hypothesis related directly to UNESCO sites. Proving that this robust methodological process can be implemented across multiple variations in scope notwithstanding the examples stated above.

Academic efforts including the marketing of WHS within or in the vicinity of airports, all-inclusive holiday packages linking WHS with accommodation and transport links and allowing for other tourism sites into the scope, not just UNESCO sites, are all examples of future academic endeavors that could aid the development of both airports and tourism in general.

Future research in this area will explore more specifically the impact that distance has on both WHS and international airport arrivals.

\section{Acknowledgement}

We would like to thank the French DGAC and more particularly to Dr. Kévin Guittet for his research and statistical data provided on worldwide airport geographical coordinates.

\section{References}

Abu Dhabi airport annual report. International arrivals 2017.

Aéroport Toulouse-Blagnac. (2014). 2014 Review and Future Plans: Traffic Results, p. 5.

Aéroport Toulouse-Blagnac. (2018). 2017: Record year for Toulouse Blagnac airport, which flies high with its international expansion at

http://www.toulouse.aeroport.fr/en/professionnels/compagnies/actualites-developpement/2017record-year-toulouse-blagnac-airport-which-flies-high-its-international-expansion . Accessed

23 November 2018. 
Aéroport Toulouse-Blagnac. (2018). All destinations at http://www.toulouse.aeroport.fr/en/passengers/flights/all-destinations?tri=popularity . Accessed 23 November 2018.

Air passenger arrivals 2017: (1.) Toulouse-Blagnac Airport 2014 review http://www.toulouse.aeroport.fr/sites/default/files/contrib/societe/lasociete/bilan_2014 en_v03 0.pdf. Accessed 22 November 2018. (2.) Montpellier Méditerranée Airport 2017 statistics https://montpellier-airport.com/amm-company/montpellier-mediterranee-airport/statisticsmontpellier-airport/ . Accessed 22 November 2018. (3.) Sydney (Kingsford Smith Airport).

Airport traffic data. Australian Bureau of Infrastructure, Transport and Regional Economics. https://bitre.gov.au/publications/ongoing/airport_traffic_data.aspx . Accessed 28 November 2018. (4.) San Antonio International Airport. City of San Antonio Aviation Department. "Statistics - San Antonio International Airport 2017. https://www.sanantonio.gov/Aviation/Financial-Information-Statistics\#33782532-2017-

Accessed 28 November 2018. (5.) Al Ain International airport Statistical Year Book of Abu Dhabi 2018, 97 https://www.scad.gov.abudhabi/Release\%20Documents/SYB_2018_EN_9Sep.pdf . Accessed 28 November 2018.

Airports Council International (2018). ACI Europe Airport Traffic Report 2017 at www.acieurope.org/. Accessed 22 July 2018.

Akhlas, A. W. (2020, February 3). Indonesia welcomes $16.1 \mathrm{~m}$ foreign tourists in 2019, coronavirus clouds tourism outlook. The Jakarta Post, Business.

Amadeus, (2018). The importance of understanding travelers' motivation, understanding why people travel to unlock industry opportunities in an Amadeus Innovation foresight paper.

AMM- Montpellier-Méditerranée Airport. Rapport statistiques 2014 : January 2014 to December 2014 at https://montpellier-airport.com/amm-company/montpellier-mediterranee-airport/statisticsmontpellier-airport/ . Accessed 23 November 2018.

AMM- Montpellier-Méditerranée Airport. Rapport statistiques 2017 : January 2017 to December 2017 at https://montpellier-airport.com/amm-company/montpellier-mediterraneeairport/statistics-montpellier-airport/ . Accessed 23 November 2018.

Bieger, T. and A.Wittmer, (2016). Air Transport and Tourism - perspectives and challenges for destinations, airlines and governments. Journal of Air Transport Management, 12(1), 40-16.

Button, K., Kramberger, T., Grobin, K., and Rosi. (2018). A note on the effects of the number of lowcost airlines on small tourist airports'efficiencies, Journal of Air Transport Management, 72, 9297.

Centre, UNESCO World Heritage. (2018). The Criteria for Selection at whc.unesco.org. Accessed 22 July 2019.

Chambre de Commerce et l'industrie Tarn (CCI). Le Tarn en quelques chiffres at http://www.obseco.fr/sites/obseco.fr/files/pdfobseco/81_le-tarn-en-quelques-chiffresmaj2017.pdf . Accessed 23 November 2018

City of San Antonio Aviation Department (2018). Statistics - San Antonio International Airport 2014 \& 2017.

Commonwealth of Australia. Australian Bureau of Infrastructure, Transport and Regional Economics. Airport traffic data, Sydney airport stats 1985-2017.

Cravidão, F., Nossa, P., Santos, N., Vidal Casellas, M. D., Costa, N.C., Aulet, S., \& Dallari, F. (2018). Tourism Management at UNESCO World Heritage Sites: Opportunities and Challenges in Tourism Management at Unesco WHS, Università della Swizzera italiana. Lugano, 24-28.

D’Abszac, E.. (2019) : Transport aérien : le trafic mondial devrait doubler d'ici 2037. $\begin{array}{llll}\text { Déplacementspros.com, } & 30 & \text { Oct. } & \text { Retrieved }\end{array}$ https://www.deplacementspros.com/transport/transport-aerien-le-trafic-mondial-devraitdoubler-dici-2037

Department of Culture and Tourism - Abu Dhabi. Statistical yearbook Abu Dhabi 2017 .

Di Giovine, M.A. (2009). The Heritage-scape: UNESCO, World Heritage, and Tourism. Lexington Books, 4. 
Direction Générale de l'Aviation Civile (DGAC), (2020). Including airport databases, the International Civil Aviation Organisation (ICAO).

Direction générale de l'Aviation civile. (2020). Airports database 2019. The International Civil Aviation Organization.

Dunne, G., Buckley, J. and Flanagan, S. (2010). Towards an understanding of international city break travel. International Journal of Tourism Research, 12(5), 409-417.

Dunne, G., Buckley, J., Flanagan, S. (2007). City Break Motivation. Journal of Travel \& Tourism Marketing, $\mathrm{n}^{\circ} 22,95-107$.

Farid, S. M., (2015). Tourism Management in World Heritage Sites and its Impact on Economic Development in Mali and Ethiopia. 595-604

Go Languedoc. International airports in France at www.golanguedoc.com/south-francetourism/international-airports-south-france.html. Accessed 6 August 2018.

Gonzalez Santa-Cruz, F. \& Lopez-Guzman, T. (2017). Culture, tourism and World Heritage Sites. Tourism Management Perspectives, 24, 111-116.

Gulf News. (2004a). Dubai 'holds special place in world travel'. 27 April.

Henderson, J. C. (2006). Tourism in Dubai: Overcoming barriers to destination development in International Journal of Tourism Research, 92.

Historic Houses Trust of NSW. Sydney Living Museums Annual Report 2016/2017.

Huang, C-H., Tsau, J-R. and, Yang, C-H. (2012). Does World Heritage list really induce more tourists? Evidence from Macau, Tourism Management, 33(6), 1450-1457, ref. 19.

Kazakov, A. and Nikolova, V. (2015). "special features in supply of "city breaks" as tourist product in destinations sofia and skopje, Issue 3, 1-14

Lyck, L. (2015). Tourism and Leisure: World Heritage as Tourism Destination Drivers. Springer Gabler, Wiesbaden, 203-222

Massidda, C. and Mattana, P. (2013). A SVECM Analysis of the Relationship between International Tourism Arrivals, GDP and Trade in Italy. Journal of Travel Research, 52(1), 93-105.

Mathieson, A., Wall, G., (1982). Tourism, economic, physical and social impacts, ed. Longman.

McKercher, B. and, Cros, H. (2012). Cultural tourism: the partnership between tourism and cultural heritage management. Chapter 2, 11.

Olipra, L. (2015). The impact of low-cost carriers on tourism development in less famous destinations at http://lifeasabutterfly.com/wp-content/uploads/2015/07/766-1042-1-PB-1.pdf . Accessed 24 November 2018.

Région Auvergne-Rhône-Alpes Press File June 2017. LA CAVERNE DU PONT-D'ARC dossier de presse, 2017. pp. 5.

Rhône-Alpes Tourism: Press File June 2014. LA CAVERNE DU PONT-D'ARC dossier de presse, juin 2014 , p. 4.

Shackley, M. (2000). visitor management: case studies from World Heritage Sites. Routledge First Edition. Conclusions chapter 12.

$\mathrm{Su}, \mathrm{Y}-\mathrm{W}$. and Lin H-L. (2014). Analysis of international tourist arrivals worldwide: the role of world heritage sites, Tourism Management, 40, 46-58.

$\mathrm{Su}, \mathrm{Y}-\mathrm{W}$., Lin, H-L. (2013). Analysis of international tourist arrivals worldwide: The role of world heritage sites. Tourism Management, 46-58.

Sydney Living Museums at https://sydneylivingmuseums.com.au/stories/short-history-hyde-parkbarracks. Accessed 28 November 2018.

Trading Economics. (2020). Indonesia Tourist Arrivals 2011-2020 data at https://tradingeconomics.com/indonesia/tourist-arrivals. Accessed 20 March 20.

Trip Advisor. (2019). Trip Barometer 2017/18 Global Report, 64.

UNESCO. (2018). World Heritage list: the decorated cave of Pont d'Arc, known as Grotte ChauvetPont d'Arc at http://whc.unesco.org/en/list/1426. Accessed 20 February 2019

UNESCO. (2018). World Heritage List "San Antonio Missions" at https://whc.unesco.org/en/list/1466 . Accessed 28 November 2018

UNESCO. (2020). Interactive list/map. https://whc.unesco.org/en/interactive-map/

UNESCO. (2018). Success stories at https://whc.unesco.org/en/107/. Accessed 30 November 2018. 
UNESCO. (2018). The criteria for selection at whc.unesco.org/en/criteria/. Accessed 22 July 2018.

UNESCO. (2018). The list "Episcopal city of Albi" at https://whc.unesco.org/en/list/1337 . Accessed 23 November 2018.

UNESCO. (2018). World Heritage List "Cultural sites of Al Ain" at http://whc.unesco.org/en/list/1343 . Accessed 28 November 2018.

UNESCO. 43rd session of the World Heritage Committee at $<$ https://www.ovpm.org/2019/07/09/43rdsession-of-the-world-heritage-committee-in-baku-azerbaijan/> Accessed 22 February 2020.

UNESCO. Introducing UNESCO at www.unesco.org/new/en/united-nations-educational-scientificand-cultural-organization/about-us/who-we-are/introducing-unesco/. Accessed 20 January 2020.

UNESCO. Interactive list/map. https://whc.unesco.org/en/interactive-map/ . Accessed 22 Feb 2020.

UNESCO. Properties inscribed on the World Heritage list - Indonesia at https://whc.unesco.org/en/statesparties/id Accessed 20 November 2018.

UNESCO. Properties inscribed on the World Heritage list - Vietnam at https://whc.unesco.org/en/statesparties/vn. Accessed 20 November 2018.

United Nations World Tourism Organisation (UNWTO). World Tourism Barometer. 18(1), January 2020. at <https://www.e-unwto.org/doi/pdf/10.18111/wtobarometereng.2020.18.1.1>, Accessed $27 \mathrm{Feb}, 2020$.

UNWTO (2013). ICAO and UNWTO affirm cooperation on joint aviation and tourism goals 18 March 2013.

UNWTO and IPSOS, (2019): Global survey on the perception of residents towards city tourism: impact and measures, (Executive Summary). Press Release, 24 January, PR № 19007, 1-22.

UNWTO, (2019). International tourist arrivals Rrach 1.4 billion Two Years Ahead of Forecasts. Press Release, 21th January.

US Department of the Interior (2018). National Park Service at https://www.nps.gov/saan/index.htm . Accessed 28 November 2018.

Vanblarcom, B. \& Burc, K. (2011). Assessing the economic impact of a UNESCO World Heritage designation. Journal of Heritage Tourism, 143-164.

Visit San Antonio. (2017). Roadmap Annual Report

WHS visits (1.) Albi - CCI OCCITANIE - OBS ECO edition 2011.Page 10. Accessed 22 November 2018. (2.) Pont d'Arc - Press dossier 2014 Region Rhone-Alpes. Accessed 22 November 2018.

(3.) Hyde Park Barracks Museum - Living Museums annual report 2009-2010

https://sydneylivingmuseums.com.au/sites/default/files/2009-2010-Annual-Report.pdf .

Accessed 22 November 2018. (4.) The Alamo - Texas General land Office Report 2014. (5.)

Cultural sites of Al Ain - Department of Culture and Tourism - Abu Dhabi, Statistical yearbook Abu Dhabi 2011 (regional visitors)

WHS visits 2017: (1.) Albi - 2016 Albi Office de tourisme: Etats généraux de janvier 2017 (2.) Pont d'Arc - 2016 Ardeche tourisme http://pro.ardeche-guide.com/la-caverne-du-pont-d-arc . Accessed 22 November 2018. (3.) Convict sites - Historic House Trust, Sydney Living Museums Annual Report 2016-2017. (4.) San Antonio Missions (The Alamo) - Texas Land Commission. http://savethealamo.com/governance.html . Accessed 28 November 2018. (5.) Cultural sites of Al Ain - Department of Culture and Tourism - Abu Dhabi: statistical yearbook Abu Dhabi 2017 (Regional visitors).

World Tourism Organisation (UNWTO). Tourism highlights 2018 edition. Page 16.

Zajac, G. (2016). The role of air transport in the development of international tourism, Journal of International Trade, Logistics and Law, 2(1), 1-8. 